\title{
AZ EGÉSZSÉGROMLÁS ÉS AZ EGÉSZSÉGMAGATARTÁS-VÁLTOZÁS KVALITATÍV VIZSGÁLATA MUNKAFÜGGÖK KÖRÉBEN
}

\author{
KUN BERNADETTE ${ }^{1 *}$ - HAMRÁK ANNA ${ }^{2}$ - KENYHERCZ VIKTÓRIA ${ }^{3}$ - \\ DEMETROVICS ZSOLT ${ }^{1}$ - KALÓ ZSUZSA ${ }^{4}$
}
${ }^{1}$ ELTE PPK Pszichológiai Intézet, Klinikai Pszichológia és Addiktológia Tanszék, Budapest
${ }^{2}$ ELTE PPK MA pszichológia program, Budapest
${ }^{3}$ ELTE PPK Pszichológiai Doktori Iskola
${ }^{4}$ ELTE PPK Pszichológiai Intézet, Tanácsadás és Iskolapszichológia Tanszék, Budapest

E-mail: kun.bernadette@ppk.elte.hu

Beérkezett: 2020. augusztus 20. - Elfogadva: 2021. január 22.

\begin{abstract}
Háttér és célok: Egyre több kutatás irányul a munkafüggöség rizikófaktorainak és következményeinek feltárására. Bár az elméleti modellek feltételezik, hogy a túlzott munkavégzés többek között az egészségi állapotra is negatív hatással van, a kutatások alapvetôen kvantitatív módszerekkel vizsgálták-e kérdést; kvalitatív vizsgálatok, amelyek a munkafüggố személyek saját élményeit elemzik, alig születtek. Célunk az volt, hogy munkafüggô személyek egészségi állapotának, egészség-magatartásának, és ezek munkavégzési szokásokkal való összefüggéseit elemezzük.

Módszer: Egy korábbi kutatásunk alapján a munkafüggóség szempontjából rizikócsoportba tartozó személyeket kértünk fel a kutatásban való részvételre, és összesen 29 fövel (15 férfi és 14 nô) készítettünk félig strukturált interjúkat. Az interjúk kitértek a személyek pályaorientációjára, munkavégzési szokásaikra, munkamotivációikra, munkafüggôséggel kapcsolatos élményeikre, testi és lelki egészségükre. Az interjúkból készült átiratok elemzése deduktív és induktív szinten is zajlott, Braun és Clarke (2006) hatlépéses módszerét követve kvalitatív témaelemzéssel történt.

Eredmények: Az interjúalanyok a túl sok munkavégzés következtében számos szempontból tapasztalták az egészségromlás jeleit. Az általános egészségromlás mellett mozgásszervi és autoimmun betegségek kialakulásáról, kardiovaszkuláris és gyomorbetegségekról, túlsúlyról, alvászavarokról és kiégésról is beszámoltak. Az egészség-magatartásuk mentén is negatív irányú változásokat tapasztaltak: az egészségtelen táplálkozás és a kevés fizikai aktivitás mellett az alvás önmaguktól való megvonása is jellemzó volt.

Következtetések: Kutatásunk rámutatott arra, hogy az érintettek a fizikai egészségi állapotukban megjelenô panaszaikat a túlzott munkavégzés és munkafüggöség következményeként irták le. Az eredményeink arra utalnak, hogy a munkafüggöség nem „pozitív addikciō", sôt, a jelenséget addiktológiai megközelítésból érdemes tárgyalni, mivel a munkafüggôség tünettanában is rokonságot mutat más függốségekkel.
\end{abstract}

Kulcsszavak: munkafüggőség, testi egészség, egészség-magatartás, kvalitatív, tartalomelemzés, viselkedési addikció

* levelezô szerzô 


\section{BEVEZETÉS}

\section{Munkafüggôség}

A nem pszichoaktív szerekkel kapcsolatos, úgynevezett viselkedési addikciók területe egyre nagyobb hangsúlyt kap az addiktológiában és a mentális zavarok területén (Demetrovics és Kun, 2010a; Demetrovics és Griffiths, 2012). Ezt jól érzékelteti az a két fontos változás, amelyeket a mentális zavarok kézikönyveinek (BNO és DSM) legutóbbi kiadásaiban láthatunk. Egyrészt, a DSM-5 (American Psychiatric Association, 2013) kézikönyvében új kategóriába, az ún. „Szerrel összefüggó és egyéb addiktív zavarok” csoportjába került átsorolásra a „Szerencsejáték használati zavar” (Gambling disorder). Másrészt, a BNO legújabb kiadásában új zavarként szerepel a „Videójátékhasználati zavar" is (Gaming disorder) (World Health Organization, 2018; Rumpf és mtsai, 2018), elismerve azt, hogy a videójáték használatának is lehet egy maladaptív formája, amely más függóségekhez hasonlatos. Az említett két zavaron kívül még számos viselkedési addikciót tartunk számon (Demetrovics és Kun, 2007, 2010b), ám az egyes jelenségekkel kapcsolatos bizonyítékok mennyisége nagyon változó (Brand és mtsai, 2020; Bôthe és mtsai, 2020; Müller és mtsai, 2019).

Az egyik feltörekvô terület a viselkedési addikciók kutatásán belül a munkafüggốség, amely bár egyre nagyobb figyelmet kap, még mindig számos megválaszolatlan kérdéssel néz szembe (Kun és Demetrovics, 2010; Atroszko, Demetrovics és Griffiths, 2020). Ugyanakkor nem elhanyagolható azon személyek aránya, akiket érint a munkafüggốség problémája: az eddigi két vizsgálatban, amelyben országos felmérést készítettek (Norvégia és Magyarország), hasonló eredményeket kaptak: a felnôtt munkavállalók kb. 8\%-át érinti a probléma (Andreassen és mtsai, 2014; Kun, Magi, Felvinczi, Demetrovics és Paksi, 2020). Ez a magas érték arra hívja fel a figyelmet, hogy a jelenséggel kapcsolatosan jóval több kutatásra lenne szükség. Ez amiatt is fontos, mivel a munkafüggôségre vonatkozóan számos tévhit és mítosz él a közgondolkodásban (Griffiths, Demetrovics és Atroszko, 2018), és ezek egyike az, hogy a jelenségre mint „pozitív addikcióra" tekintenek sokan. Ez a megközelítés azonban sajnos téves, hiszen maga a probléma, a munkafüggóség definícióinak egyik legfontosabb eleme, hogy a túlzott munkavégzés miatt a személy számos kedvezôtlen, káros következménnyel néz szembe. Így a „pozitív” jelzô semmiképpen sem indokolt (ahogy alapvetôen egy függôség esetében sem).

A munkafüggóség problémáját elôször a hetvenes évek elején írták le. Oates (1971) a zavart az alkoholizmushoz hasonlította, és azt hangsúlyozta, hogy a munkafüggó („workaholic”) személynek olyan mértékben van szüksége a túlzott mennyiségú munkára, hogy az már kifejezetten káros hatással van a személy egészségi állapotára, társas kapcsolatainak minôségére és pszichés jóllétére is. A késôbbiekben a munkafüggôséget különbözô tényezôk alapján próbálták megragadni, mint a munkával töltött idô (Mosier, 1982), a munkával kapcsolatos attitúdök (Machlowitz, 1980), a munkával kapcsolatos késztetés, involváltság és élvezet kombinációi (Spence és Robbins, 1992). Továbbá voltak, akik a munkafüggóséget egy speciális viselkedési mintázatként írták le (pl. Scott, Moore és Miceli, 1997), míg mások elsôsorban a maladaptív, addikciós jellegét hangsúlyozták a jelenségnek (Porter, 1996; Robinson, 1998). A szakirodalom- 
ban általánosan elfogadott az ún. „komponens modell” (Griffiths, 2005, Griffiths és Karanika-Murray, 2012), amelyet különbözó problémák (pl. szerencsejáték-zavar, videójáték-függôség vagy testedzés-függôség) esetén is jól alkalmazhatunk. Ez a megközelítés az addikciók hat fő komponensét írja le, és ezeket a munkafüggóség vonatkozásában az alábbi módon érhetjük tetten: 1. Kitúnés (szaliencia): a személy életében a munkavégzés a legfontosabb; a munkával kapcsolatos teendôk uralják a személy gondolatait, érzéseit és viselkedését is. 2. Hangulatmódosítás: a személy arra használja a munkavégzést, hogy általa pozitívabb hangulati, érzelmi állapotba kerüljön, és elkerülje a kellemetlen hangulati élményeket és feszültségeket. 3. Tolerancia: a személy egyre többet és többet dolgozik annak érdekében, hogy megfelelően érezze magát (pl. ne legyen feszült vagy ingerült). 4. Megvonás: ha a személy valamilyen oknál fogva nem tud dolgozni, kellemetlen - elsôsorban pszichés - megvonási tüneteket él meg; feszültté és ingerültté válik, szorongást, hangulatingadozást, idegességet, búntudatot, depresszív tüneteket tapasztalhat. 5. Konfliktus: a túlzott mennyiségú munkavégzés a személy életében számos területen okoz konfliktusokat: rendszeresen összetúzésbe kerül hozzátartozóival (interperszonális konfliktus), a túlzott munkavégzés konfliktusba kerül az élet egyéb területeivel (pl. szabadidôs tevékenységek, háztartási és családi feladatok), továbbá belsố küzdelmet is megtapasztal a személy, mivel ô is érzékeli a túlzott munkavégzés káros következményeit (intrapszichés konfliktus). 6. Visszaesés: bár a munkafüggő személy idôrốl idôre megpróbálja csökkenteni a munkavégzését, és más tevékenységeknek is próbál nagyobb tered engedni, az ezzel kapcsolatos változtatások nem tudnak tartósak lenni, és ismételten visszacsúszik egy maladaptív munkavégzési módba. Fontos felhívnunk a figyelmet arra, hogy a munkafüggôség problémáját célzó mérôeszközök alapvetôen szúrô kérdôivekként múködnek, és elsôsorban a jelenség kockázatát tudják megbecsülni (Clark, Smith és Haynes, 2020; Urbán és mtsai, 2019). Mivel a munkafüggóségrôl jelenleg nem állnak rendelkezésre hivatalos diagnosztikai kritériumok és olyan pszichometriai eljárás sem, amelynek alapján egy személyrôl egyértelmúen kijelenthetô volna, hogy ó munkafüggô-e vagy sem, így - ahogy szokás ezt más problémák, akár viselkedési addikciók esetében - a kutatásokban ezeket a szûrô kérdôíveket alkalmazzák. Ezek megbízható és érvényes módszerek arra, hogy a munkafüggôség szempontjából a kockázati csoportba tartozó személyeket azonosítsuk (pl. Orosz és mtsai, 2016; Urbán és mtsai, 2019).

A munkafüggôség addiktológiai szempontú megközelítésében tehát az ártalmas következmények és a distressz megélése mindenképpen kulcsfontosságúnak tekinthetôk. A kutatások többek között arra keresik a választ, hogy milyen kockázati tényezók állnak a munkafüggôség hátterében, továbbá, hogy milyen kedvezôtlen kimenetelekkel járhat az, ha valaki túlzottan sokat dolgozik. A kockázati tényezók sorában több személyiségvonást - pl. alacsony önértékelés, magas perfekcionizmus, negatív affektivitás, kényszeresség - is találhatunk (Clark, Michel, Zhdanova, Pui és Baltes, 2016; Kun, Takács, Griffiths, Richman és Demetrovics, 2020), ugyanakkor egyéb tényezók és azok interakciói is igen lényegesek lehetnek (Atroszko, Demetrovics és Griffiths, 2019; Griffiths és mtsai, 2018). Ezen tényezôk között érdemes megemlíteni a munkavégzés és a munkahely strukturális tényezőit (pl. az elvégzendô feladat jellege, ismerôssége vagy újdonsága; anyagi és egyéb juttatások és visszajelzések stb.), ahogy a különbözố szituációs faktorok is hatással lehetnek a munkafüggôség kialakulására (Mazzetti, 
Schaufeli és Gugliemi, 2014; Griffiths és Karanika-Murray, 2012). Utóbbiak közé tartozik például a munkahelyi társas környezet, a munkahelyi hangulat, a szervezeti felépítés és a szervezeti kultúra is (Griffiths, 2011). A munkahelyek között is létrejöhetnek ún. „addiktív szervezetek” (Schaef és Fassel, 1988), amelyek növelhetik a munkafüggôség kialakulásának kockázatát. Noha a területen végzett kutatások többsége keresztmetszeti jellegénél fogva nem fogalmazhat meg egyértelmú ok-okozati viszonyokat a munkafüggóség és a vele együtt járó tényezők között, számos vizsgálat arra utal, hogy a munkafüggóségnek komoly kockázata van mind a fizikai, mind a mentális egészségre nézve (Sussman, 2012).

\section{Munkafüggôség és fizikai egészség}

A globalizáció térnyerésével, a kommunikáció és a technológia elmúlt évtizedekben lezajlott rohamos fejlôdésével, a fogyasztói társadalom eluralkodásával párhuzamosan egyre több változás zajlik le a munkahelyek világában. A cégek alkalmazkodva ehhez az új környezethez egyre több és gyorsabb munkát várnak el a dolgozóktól (Porter és Kakabadse, 2006). A technikai fejlôdéssel együtt bizonyos mozgásszervi és mentális betegségek korábbi életkorban jelennek meg. Ehhez hozzájárulhatnak az olyan tényezôk is, mint a fizikai munka és a napi testmozgás lecsökkenése, az ülömunka elterjedése vagy a tömegközlekedés kockázatai (Borbély és Pecze, 2006).

A munkahelyi stressznek, azok összetevőinek és következményeinek igen széles a szakirodalma, ahogy arról is igen sok kutatás született, hogy a munkahelyi stressz számos közvetett és közvetlen módon tehet kárt az egészségi állapotban (Ganster és Rosen, 2013). Munkahelyi stresszt okozhat például, ha a személy azt éli meg, hogy a munkaadó részérôl túlzottan nagy a kontroll, ha túlzottan alacsonyak/magasak a felé támasztott követelmények, ha szerepkonfliktussal vagy szerep-kétértelmúséggel kell szembenéznie, vagy ha nagyon alacsony munkahelyi társas támogatást tapasztal (Cooper és Davidson, 1987; Ganster és Perrewé, 2011; Karasek, 1979; Karasek és Theorell, 1990). Ezek a tényezók egyértelmú pozitív kapcsolatot mutatnak a szív-érrendszeri betegségekkel és az abból fakadó mortalitással is (Belkic, Landsbergis, Schnall és Baker, 2004; Kristensen, 1996). A munkahelyi stressz emellett kedvezôtlenül befolyásolja az egészség-magatartást is (Salavecz, 2008, 2011). A túlzott munkahelyi stressz például növeli a dohányzás és az alkoholfogyasztás kockázatát (Frone, 1999; Peter, Alfredsson, Hammar, Siegrist, Theorell és Westerholm, 1998), az egészségtelen táplálkozási szokások jelenlétét és az elhízás kialakulását (Kivimaki és mtsai, 2006), illetve az alvási szokások megváltozásához és alvászavarokhoz is vezethet (Kecklund és Akerstedt, 2004). Mindezen egészség-magatartási tényezók pedig káros hatással vannak a személy testi és lelki egészségére egyaránt (Siegrist és Rödel, 2006).

Maga a túlzott mennyiségú munka is kifejezetten veszélyeztetố tényezô lehet a stressz és azzal összefüggố betegségek kialakulása és a kiégés szempontjából. Japánban olyan súlyos népegészségügyi problémát jelentenek a túlzott munkavégzés okozta egészségügyi ártalmak, hogy 1982-ben külön kifejezést hoztak létre a jelenség leírására: a „karoshi” szó azt jelenti, hogy „túlzott munkavégzés miatt bekövetkezett halál”. A halál oka általában szív- és érrendszeri betegségekhez köthetô. Egyes kutatók szerint 
pedig a japán lakosság szív- és érrendszeri problémákkal kapcsolatos elhalálozásainak körülbelül egyharmadában karoshiról van szó, azaz a túlzott munkavégzés és az ahhoz köthetô stresszes életmód eredményezi a halált (Nishiyama és Johnson, 1997).

A munkafüggók esetében, akik rengeteget dolgoznak, emellett saját magukkal szemben túlzottan magas elvárásokat támasztanak, folyamatosan megerôsítésre és elismerésre vágynak (Porter, 1996; Robinson, 1998), illetve szoronganak attól, hogy eleget dolgoznak-e, és kellóképpen jól teljesítenek-e, könnyen elvárható a magasabb stressz-szint jelenléte. Ez azzal is összefügg, hogy a munkafüggók nagyon nehezen tudnak kikapcsolódni és elszakadni a teendôiktôl: gondolatban még akkor is dolgoznak, vagy a feladataikon jár az eszük, amikor fizikailag valamilyen más tevékenységet végeznek (Fassel, 1992; Porter, 1996). Ahogy Ng, Sorensen és Feldman (2007) modelljében felvázolja, a munkafüggôség során mind közvetlen tényezók - mint a kevesebb kikapcsolódás és testmozgás -, illetve közvetett tényezôk - mint a kedvezôtlenebb egészség-magatartási formák (kevesebb alvás, gyakoribb dohányzás és egészségtelenebb táplálkozás) - hozzájárulhatnak az egészségügyi problémák kialakulásához. A munkafüggôséggel kapcsolatos kutatások egy részében arra keresték a választ, hogy a zavarban szenvedôk között miként tapasztalhatók a különbözô egészségügyi panaszok és betegségek. Önjellemzéses kérdôíves módszertanú kutatások keretében többen is azt találták, hogy a munkafüggôség tünetei együtt járnak az emelkedett szintú munkahelyi stresszel (Spence és Robbins, 1992; Kanai, Wakabayashi és Fling, 1996), és ezt egy átfogó metaanalitikus tanulmány is alátámasztotta (Clark és mtsai, 2016). Emellett szintén keresztmetszeti, kérdốives kutatások bizonyítják azt, hogy a munkafüggôség szempontjából kockázati csoportba sorolt személyek között gyakrabban jelentkeznek alvászavarok és kimerültség, több alkoholt fogyasztanak, gyakrabban panaszkodnak hátfájásra, többet hiányoznak munkahelyükról egészségügyi okok miatt, és kedvezôtlenebb pszichés jólléttel jellemezhetôk (Salanova és mtsai, 2016; Matsudaira és mtsai, 2013; Avanzi, Van Dick, Fraccaroli és Sarchielli, 2012; Yang, Qiu, Lau és Lau, 2020). Egy hazai reprezentatív lakossági felmérés szerint azok a személyek, akik magasabb munkafüggóség-pontszámot kaptak, elégedetlenebbek voltak a saját egészségi állapotukkal (Kun, Magi és mtsai, 2020). Mindezek mellett a munkafüggóség egyértelmú együtt járást mutat a kiégéssel is: nem csupán a túlhajszolt munkavégzés, a sok munkahelyi stressz, hanem a munkafüggôség jelenléte is növeli a kiégés kialakulásának kockázatát (Clark és mtsai, 2016).

\section{Kvalitatív kutatások a munkafüggóség területén}

A munkafüggôséggel kapcsolatos, eddig összefoglalt kutatási eredmények alapvetôen kvantitatív módszertanon alapultak, és rendkívül kevés kvalitatív kutatás készült eddig a területen, és azon belül igen kevés adattal rendelkezünk az egészségi állapotra vonatkozóan. Porter és Kakabadse (2006) sokat dolgozó informatikusokkal és menedzserekkel készítettek interjúkat és fókuszcsoportos beszélgetéseket. Ezek elemzése során azt találták, hogy a munkafüggóként jellemzett személyek nagyon nehezen tudnak kikapcsolni, relaxálni, és akár még a nyári vakációjuk idején is folyamatosan a számítógépük elôtt ülnek és dolgoznak. Kirrane, Breen és O’Connor (2017) írországi menedzserek- 
kel végzett interjúk alapján azt állapították meg, hogy a munkafüggó személyek magasabb distresszt élnek meg, emellett türelmetlenebbek, impulzívabbak, és többször kerülnek konfliktusba munkatársaikkal. Ezek a jellemzések párhuzamba állíthatók az ún. „A típusú személyiség”-gel (Kuiper és Martin, 1989), amelyről pedig számtalan kutatás bizonyította, hogy összefüggést mutat a kedvezôtlenebb egészségi állapottal, pl. szív- és érrendszeri betegségek kialakulásával (Booth-Kewley és Friedman, 1987). Végül Russell (2013) tanulmányát is érdemes megemlítenünk, amelyben a szerzó az amerikai Névtelen Munkafüggốk (Workaholics Anonymous) közösség által írt sajátélményú szövegek tartalomelemzését végezte el. Az érintettek úgy írtak problémájukról, mint ami egy progresszív betegség, és amelyet csak akkor vesz észre a személy, ha már nagy a baj: például egészségügyi problémák jelentkeznek vagy társas kapcsolatai romlottak meg súlyosan. Az élettörténeti leírásokban volt, aki azt emelte ki, hogy az intenzív munkavégzés közben nem vett tudomást sem a fáradtságról és kimerültségről, sem pedig a testi vagy érzelmi fájdalomról.

\section{A kutatás célja}

A fentiek alapján megállapíthatjuk, hogy az eddigi néhány, elsốsorban kérdôives módszertanú, kvantitatív kutatás arra utal, hogy a munkafüggôség esetében mind kedvezôtlen egészség-magatartási szokások, mind pedig az egészségromlás tünetei is tapasztalhatók. Ezek az összefüggések bár érvényesek, nem kellóképpen árnyaltak abból a szempontból, hogy milyen módon kapcsolódnak egymással az egészségügyi problémák és a munkafüggôség tünetei. Úgy véljük, az érintettek személyes tapasztalatai jóval árnyaltabbá tehetik az eddigi tudásunkat errôl a területrôl. A kutatás célja tehát egyrészrốl a munkafüggôség és a fizikai egészség közötti összefüggések feltárása, másrészrôl az egészség-magatartási szokások megismerése munkafüggóségben érintett személyek beszámolói, saját értelmezésük alapján. Tudomásunk szerint hasonló, fenomenológiai megközelítésú kutatás eddig nem készült Magyarországon.

\section{MÓDSZER}

\section{Eljárás és vizsgálati személyek}

A vizsgálati személyeket egy 2018 tavaszán lezajlott kvantitatív vizsgálat (Kun, Urbán, Bôthe, Griffiths, Demetrovics és Kökönyei, 2020) alanyai közül toboroztuk. Ezen online vizsgálatban aktív munkaviszonnyal rendelkezô, felnôtt személyek vettek részt, a kutatás fố célja pedig a munkafüggốség háttérdimenzióinak, pszichológiai jellemzôinek feltárása volt. A munkavégzési szokásokra vonatkozó kérdések mellett számos különbözô skálát töltöttek ki, melyek személyiségdimenziókra, munka- és teljesítménymotivációkra és társas kapcsolati tényezôkre irányultak. A résztvevốk az online adatfelvétel során kitöltötték a WART-R kérdőívet is (Munkafüggóség Rizikója Teszt [Work Addiction Risk Test], Robinson, Post és Khakee, 1992; Urbán és mtsai, 2019), amelynek segítségével meghatározhatók voltak a munkafüggôség szempontjából magas rizikójúnak tekinthetố személyek (minimum 67 pontot szereztek a maximális 
100 pontból). A kérdőív végén valamennyi résztvevő nyilatkozott arról, hogy megkereshetjük-e jövôbeli kutatásunk során, és e célból megadhatta az e-mail-címét. A 1743 pozitív választ adó közül választottuk ki a magas rizikójú személyeket (716 fô), akik közül véletlen kiválasztással, több körben kerestünk meg összesen 150 személyt.

A vizsgálati személyekkel elôre egyeztetett időpontban készítettünk interjút a kutatást lebonyolító intézményben, 2019. október és 2020. január között. A tájékoztatás és az adatkezelés ismertetése mind szóban, mind írásos formában megtörtént, ezeket az interjúalanyok aláírták. Az interjút minden alkalommal egy fố készítette, összesen 8 fơ. Az interjúerek között 6 fó viselkedéselemzô BA-diplomával rendelkezett, és pszichológia mesterképzésben vett részt, 1 fố pszichológia doktori program hallgatója volt, és 1 fố pszichológia PhD-fokozattal rendelkezett. Az interjút készítô személyek egy 3 alkalmas felkészítô programban vettek részt, melyet a kutatás két vezetôje tartott. A felkészítés során a személyek részletes útmutatást kaptak a kutatás célját, elméleti alapjait és módszerét illetôen. Ezen felkészítés során a kollégák lépésrôl lépésre vonatkozó tájékoztatást kaptak az interjúk menetéról, ezzel biztosítva, hogy minden kolléga pontosan ugyanúgy valósítsa meg az interjú felvételét. Az interjúk 60-90 percet vettek igénybe, ezeket hangfelvevô eszközökkel rögzítettük, és elektronikus leirat készült belôlük. Minden személyes adatot szigorúan bizalmasan kezeltünk, kizárólag a kutatócsoportban részt vevôk között osztottuk meg. A kutatásban a résztvevôk önként vettek részt, a folyamat bármikor szüneteltethetô vagy megszakítható volt. Az interjúalanyok a kutatásban való részvételért motivációs ajándékot kaptak. A kutatást a kutatóhely etikai bizottsága jóváhagyta, továbbá a kutatás során végig a helsinki nyilatkozat alapelveit követtük.

A célszemélyek felkérése több körben történt, mivel a személyek többsége nem reagált a megkeresésre. Egy-egy körben 30 főnnek küldtünk ki felkérô levelet, ezt öszszesen 5 körben tettük, 150 fó meghívásával. A megkeresett személyek közül a többség ( $n=118)$ nem reagált az e-mail-ünkre, néhány személy esetében $(n=3)$ pedig valamilyen technikai okból kifolyólag nem tudott létrejönni a találkozás (pl. nem találtunk megfelelô idôpontot, vagy a személy másik országban élt, így nem tudott személyesen megjelenni az interjún). Összesen 29 interjú készült (15 férfi és 14 nô). A legfiatalabb résztvevô 27 éves, a legidôsebb 56 éves, a minta átlagéletkora 37 év. Végzettségüket tekintve 6 fő (21\%) rendelkezett érettségivel mint legmagasabb iskolai végzettség, a többi 23 fônek (79\%) fốiskolai, egyetemi vagy doktori fokozatuk volt. Foglalkozásukat tekintve az alábbi területekrôl érkeztek a résztvevôk: pénzügy (5 fő), informatika (5 fö), menedzsment ( 4 fö), mérnök, technikus (3 fö), kereskedelem (3 fö), tudomány (3 fő), magáncégvezetô (3 fö), rendezvényszervezés (1 fő), oktatás (1 fô) és segítô szakma (1 fô). Beosztásukat tekintve volt alsó- (7\%), közép- (31\%) és felsôvezetô $(10 \%)$, diplomához kötött szellemi munka (35\%), közvetlen termelésirányító (3\%), alkalmazott (3\%) és vállalkozó $(10 \%)$ is. A mintánkból ketten $(7 \%)$ élnek községben, hárman $(10 \%)$ egyéb városokban, és 24-en $(83 \%)$ a fôvárosban.

\section{Az adatgyújtés módja}

Az interjú megkezdése elôtt a vizsgálati személyek az alábbi szociodemográfiai és munkavégzéssel kapcsolatos kérdésekre válaszoltak: nem, születési idő, lakóhely, legmagasabb iskolai végzettség, foglalkozás és munkahelyi beosztás. A vizsgálatban fé- 
lig strukturált interjút használtunk, amelyben az interjúalanyokat megkérdeztük a munkájukkal kapcsolatos körülményeikrôl, szokásaikról és motivációikról, személyiségbeli és társas jellemzőikrôl, pályaorientációjukról, karrierjükrôl, szabadidôs tevékenységeikrôl, egészség-magatartásukról és testi és lelki egészségükrôl, illetve a munkafüggőséggel kapcsolatos vélekedéseikrôl (1. 1. táblázat). A félig strukturált interjú a definíciója (Kvale, 1996; Szokolszky, 2004) szerint a leggyakrabban használt forma a tematikus-kvalitatív interjúkban. Az interjút elôre kidolgozott interjúterv alapján végezzük, tehát egy konkrét téma áll a középpontjában (jelen esetben a munkavégzés, munkafüggóség). Ugyanakkor nyitottság van a válaszoló gondolataira, így lehet elốcsalogatni a tapasztalatok egyéni megélését, személyes jelentését. Tehát van egy terv, de fontos, hogy az interjúkészítô hagyatkozzon az interjúalanyra is. A kérdéseket egyrészrôl a munkafüggôséggel kapcsolatos legismertebb elméletek és a rendelkezésre álló kutatási eredmények alapján állítottuk össze (lásd pl. Clark és mtsai, 2016; Griffiths és mtsai, 2018), továbbá nagymértékben figyelembe vettük az általunk lefolytatott korábbi, online kérdőíves kutatást (Kun, Urbán és mtsai, 2020) is: olyan témakörök mentén szerettünk volna személyes, saját élményen alapuló ismereteket szerezni, amelyek majd kiegészíthetik, árnyalhatják a kvantitatív adatfelvétellel kapott eredményeinket. Jelen elemzés során elsôdlegesen a testi egészséggel és stresszel kapcsolatos témákra fókuszáltunk. Az interjúkészítô elôször hellyel kínálta az interjúalanyt, majd a tájékoztatást és a szociodemográfiai kérdéseket követôen az elôre meghatározott nyitott kérdéseket a megadott sorrendben feltette az interjúalanynak. Ha szükségesnek látta, pontosító kérdéseket is alkalmazhatott. Az utolsó kérdést követôen megköszönte a részvételt, átadta a motivációs ajándékot, majd a felek elbúcsúztak egymástól. Az interjúkról hangfelvétel, majd szó szerinti átirat készült. A teljes adatbázis nagysága: 217982 szó.

1. táblázat. Az interjúk során alkalmazott kérdések fốbb témakörei, példákkal illusztrálva

\begin{tabular}{|c|c|}
\hline Témakör & Példakérdések \\
\hline Karrierút bemutatása & $\begin{array}{l}\text { Mióta dolgozik ebben a pozícióban, és hogyan alakult } \\
\text { a karrierje, míg jelen munkaköréhez ért? }\end{array}$ \\
\hline Munkakörülmények bemutatása & $\begin{array}{l}\text { Mennyire jellemzó önre, hogy otthon is dolgozik? } \\
\text { Mennyire rugalmas a munkaideje? }\end{array}$ \\
\hline A munkavégzés intenzitása & $\begin{array}{l}\text { Általában mennyit dolgozik egy átlagos munkanapon? } \\
\text { Mennyi szabadideje van, és mivel szereti azt tölteni? }\end{array}$ \\
\hline Önjellemzés & $\begin{array}{l}\text { Hogyan jellemezné önmagát? Mennyire elégedett az } \\
\text { életével? }\end{array}$ \\
\hline Testi és lelki jóllét & $\begin{array}{l}\text { Összességében hogyan érzi magát a bőrében? } \\
\text { Használ-e rendszeresen valamilyen szert, amivel fokoz- } \\
\text { hatja aktivitását, frissességét? }\end{array}$ \\
\hline Társas kapcsolatok & $\begin{array}{l}\text { Van-e olyan a környezetében, aki arról panaszkodott, } \\
\text { hogy túl sokat dolgozik? Milyen a kapcsolata a kollé- } \\
\text { gáival? }\end{array}$ \\
\hline Munkafüggőség és tünetei & $\begin{array}{l}\text { Milyen az önnek, ha dolgozni szeretne, de valaki/valami } \\
\text { akadályozza ebben? Hogyan írná le azt a személyt, aki } \\
\text { munkafüggó? }\end{array}$ \\
\hline
\end{tabular}




\section{Adatelemzés}

Az átiratok elemzése kvalitatív tartalomelemzéssel, ezen belül pedig témaelemzéssel (Braun és Clarke, 2006) készült. A tematikus tartalomelemzés egy tág fogalom, amely egy ritkán elismert, mégis széles körben alkalmazott kvalitatív elemzés módszer a pszichológián belül (Braun és Clarke, 2006). Braun és Clarke (2006) cikkükben felvázolják, hogy mi a témaelemzés, elhelyezve más kvalitatív módszerek mellett, illetve támpontként egy saját tapasztalataikra épüló iránymutatót írnak le, szorgalmazva ezzel a témaelemzés mint önálló kvalitatív módszer létjogosultságát. A módszer hat lépésbôl áll, ezek közül azonban több megegyezik más kvalitatív módszertan lépéseivel. 1. Az elsố lépés az adatok megismerése. Az elhangzott interjúk szó szerinti átírása a rengeteg idô, ezzel járó frusztráció és nehézség ellenére kitûnô kezdôlépése az adatok megismerésének. Fontos a gyújtött anyagok teljes ismerete, mélységeinek feltárása, ami a teljes anyag többszöri részletes, aktív elolvasását jelenti. Ezen folyamat során érdemes a fôbbb benyomásokat, mintázatokat, gondolatokat kigyújteni. Bár ez a rész nagyon idôigényes, mégis fontos alapot biztosít az elemzés további részében, ezért elmaradhatatlan lépése a folyamatnak. 2. A második lépés a kezdeti kódok generálása. Az átírást, átolvasást és az ötletlista létrehozását követốn kódok alkotása következik, melyek segítségével az adatokat értelmezhetô csoportokba tudjuk rendezni. A kódokat a teljes adatállományon végighaladva lehet csoportosítani, akár manuálisan, akár szoftveres programmal, ami megkönnyíti a címkézést, a kódok rendszerezését, átláthatóságát és a visszakeresést is a kódcsoportok között. Érdemes annyi témát kódolni, amennyit csak lehet, mert sosem tudhatjuk, mire lesz késôbb szükségünk, vagy mi válik hangsúlyossá. Kivonatokat készítünk a kódokból, amit késôbb át is lehet nevezni és csoportosítani, több vagy más csoportba beletenni, hiszen különféle témákban is elókerülhetnek bizonyos kódok. 3. A harmadik lépés a témák keresése. Miután megneveztük, csoportosítottuk és listáztuk a kódokat, egy szélesebb értelmezési szintre lépve keressük a témákat, amelyeket ezek a kódok lefednek és kirajzolnak. Ebben a szakaszban hasznos lehet vizuális ábrázolások használata a különbözô kódok témákba rendezésében. Ekkor kezdünk el gondolkodni a kódok, a témák és a témák különbözô szintjei közötti kapcsolaton. Ennél a szakasznál rajzolódnak ki a leghangsúlyosabb témák, amelyekkel a késôbbiekben szeretnénk foglalkozni. 4. Negyedik lépésként áttekintjük a témákat. Itt tisztul le, hogy melyek azok a témák, amelyek igazán jelen vannak. Lesznek témák, amelyeket elvethetünk, és lesznek, amelyek akár további témákra bonthatók. A témákon belüli adatoknak értelmesen össze kell kapcsolódniuk, miközben világos és azonosítható különbségeknek kell lenniük a témák között. 5. Az ötödik lépésben kerül sor a témák definiálására és elnevezésére. Ezen a ponton meghatározzuk és tovább finomítjuk azokat a témákat, amelyeket bemutatunk az elemzésben, és vizsgáljuk a hozzájuk tartozó adatokat. Ez alatt azt értjük, hogy megfogalmazzuk az egyes témák lényegi részét, és meghatározzuk, hogy az egyes témák milyen szempontból rögzítik az adatokat. A témáknak címeket adunk, melyeknek tömörnek és hatásosnak kell lenniük, hogy azonnal át tudják adni az olvasónak a téma esszenciáját. 6. Végsố lépésként elkészítjük a jelentést. A témaelemzés elkészítésének feladata az, hogy elmondja az adatok bonyolult történetét oly módon, hogy az olvasót meggyoózze elemzésünk érdemérôl és érvényességérôl. A jelentés tömör, koherens, logikus, nem ismétlôdô, 
és érdekes beszámolót ad az adatokról. Olyan adatkivonatok kerülnek kiválasztásra, amelyek jól bemutatják az adott témát. A kivonatokat be kell ágyazni egy elbeszélésbe, amely meggyôző́n szemlélteti azt a történetet, amelyet az adatokról mesél, ezenfelül párhuzamba kell állítani a kutatási kérdéssel (Braun és Clark, 2006).

Az adatokat a kutatócsoport tagjai vették fel, az adatelemzést egymástól függetlenül a második és a negyedik szerzố végezte el. Az elemzôk számára a hatlépéses módszer során számos választási, döntési lehetôség merül fel, ezekre még az elemzés elốtt válaszolni kell. Ez a módszer folyamatos reflektivitást és egyfajta dialógust igényel a kutatók részérôl, továbbá fontos, hogy a kutatók közös elméleti keretben szemléljék és vizsgálják a megismerni kívánt adatokat. Az elsô ilyen dilemma, hogy mi számít témának. Téma az, ami megjelenik a kutatási kérdésünkben, és ami az adatok ismeretében folyamatosan fejlődhet és finomodhat. A második dilemma az elemzés induktív vagy deduktív megközelítésére vonatkozik. Jelen adatelemzés deduktív és induktív szinten is zajlott. Deduktív módszer alatt egy elméleti elemzést értünk, ahol felhasználunk valamilyen feltárt tudásrendszert, amelybe próbáljuk beilleszteni a kapott adatokat. Az induktív elemzés pedig egy adatvezérelt módszer, amikor nincs még kutatás az adott témában, hanem az adatok jelenítik meg magát az új témát, új kutatási eredményt. A harmadik dilemma az elemzés szemantikus vagy látens szintjére vonatkozik. Szemantikus szintú elemzésnél a felszíni tartalmakat vizsgáljuk, ahol elfogadjuk, hogy amit az interjúalany mond, az reprezentálja a valóságot, míg látens szintú elemzésnél mögöttes tartalmakat vizsgálunk. A témaelemzés során e három dilemma mentén olyan mintázatokat keresünk a kódok között, amelyek nem lennének láthatók egy kérdốives kutatás eredményeiból.

A szakirodalmi eredmények alapján a deduktív elemzéshez 1. az egészségmagatartás-változás és 2. az egészségromlás témaköröket határoztuk meg. Az egészségmagatartás-változás kategóriájába olyan témákat soroltunk, amelyeket a vizsgálatban részt vevôk olyan tevékenyég- vagy viselkedésváltozásként írnak le, amely összefüggésben van a túlzott munkavégzéssel, és negatív hatással jár az egészségükre nézve. A szakirodalom szerint ilyen az egészségtelen táplálkozás, mozgáshiány, alvással kapcsolatos magatartások (Frone, 1999; Peter és mtsai, 1998; Salavecz, 2008, 2011). Az egészségromlás alatt a túlzott munkavégzés következtében létrejött testi következményeket, betegséget értettük, mint például az alvászavart és elhízást (Kecklund és Akerstedt, 2004; Kivimaki és mtsai, 2006). Az induktív adatelemzés lehetôvé tette, hogy a túlzott munkavégzés és a fizikai egészség témakörében megjelenő további felbukkanó tartalmakat is elemezzük. Az elemzést a szövegek szemantikus rétegének vizsgálatával végeztük, és arra fókuszáltunk, hogy az interjúalanyok mit mondanak. Az elemzéshez a teljes korpuszt felhasználtuk, de azokat a részeket elemeztük részletesen, amelyek a túlzott munkavégzés és a fizikai egészség összefüggéseit mutatták be. A két elemzô egymástól függetlenül végezte az elemzést, majd konszenzusra jutottunk a vizsgálati tárgyra vonatkozó szövegrészletekrôl. Az adatelemzésnél alapvetôen Braun és Clarke (2006) hatlépéses módszerét követtük, amely egy nemlineáris folyamatként írható le, tehát a lépések nem szigorúan követik egymást, hanem dinamikusan változnak. A szövegek megismerése már a beszélgetésekkor kialakított személyes hangvételben megkezdôdött, amit aztán az újrahallgatás és gépelés követett. Az interjúk többszöri elolvasását és nyílt elemzését kiegészítette a fizikai egészségromlás és az egészségmagatartás-változás témaköreinek feltárása. A kódolás elvégzése után az elsô és a negyedik szerzô össze- 
gezte a kódokat. A kódolási folyamathoz az Atlas.ti Cloud Beta programot használtuk (Atlas.ti, 2018). Az Atlas program nagymértékben segíti, gyorsítja és átláthatóbbá teszi a sokszor nagy méretû kvalitatív adatkorpuszok feldolgozását. Lehetôvé tette számunkra a szövegszintú kódolási munkát, illetve vizualizációs elemei segítették az adatok feldolgozását. Végül arra is használtuk, hogy az adatokat kategóriákba rendezzük, és azokon elvégezhessük az összehasonlító elemzést is (Sántha, 2017). Az elemzés során a Document Manager menüpontot az elkészült átiratok feltöltésére és áttekintésére, a Code Manager menüpontot a kódok megalkotására és csoportosítására használtuk, és végül a Quotation Manager menüpont az idézetek áttekinthetôségében, szövegekben való elôfordulásuk közötti könnyú eligazodásában és visszakeresésükben nyújtott segítséget.

\section{EREDMÉNYEK}

A vizsgálatban elôzetesen meghatározott két témakörben, vagyis az 1. egészségmagatartás-változás témakörében az egészségtelen táplálkozás és az alvás önmaguktól megvonása jelent meg, a 2. egészségromlás témájában az általános egészségromlás mellett konkrétan beszámoltak: mozgásszervi betegségekrôl, inzulinrezisztencia kialakulásáról, kardiovaszkuláris és gyomorbetegségekrôl, alvászavarról, valamint túlsúlyról. Az alvás témája tehát mind a két fố témakörben megjelent: az egészségmagatartás-változás esetében olyan tartalmakat soroltunk az „alvási szokások megváltozása” kategóriába, amelyeknél az alvási magatartás közvetlen (szándékos) vagy közvetett megváltozása jelent meg, ezzel szemben az egészségromlás kategóriánál az „alvászavar” azt jelöli, ahol az érintetteknél már egyértelmúen kialakult egy egészségügyi probléma, és tartós zavarról beszélhetünk. Ezeken kívül az elemzés feltárta az egészségromlás mint fordulópont és a kiégés mint az egészségromlás tünete témakörét. Eredményeinket az illusztratív

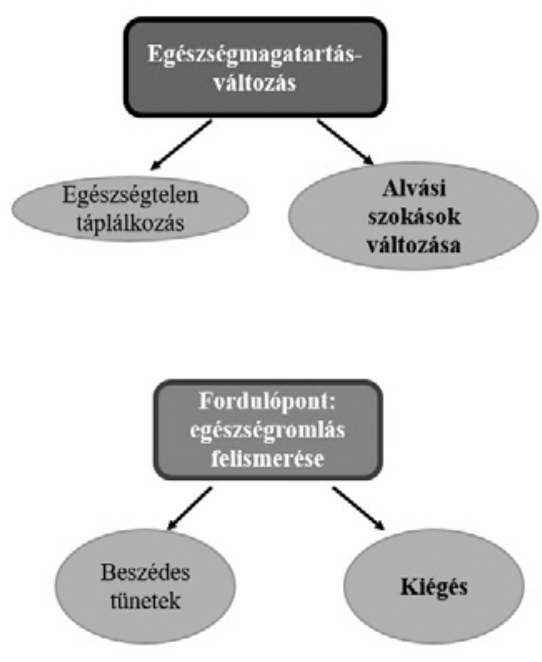

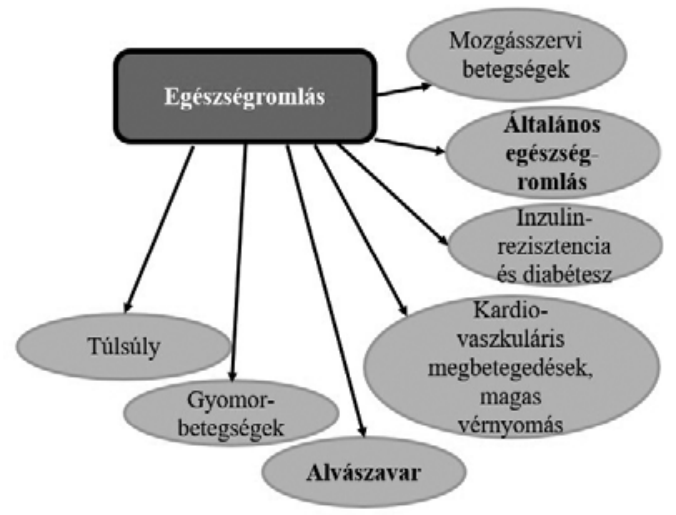

1. ábra. Tematikus térkép, amely bemutatja, hogy milyen, a fizikai egészséggel összefüggő fơ- és altémák bontakoztak ki a munkafüggôség szempontjából érintett személyekkel készült interjúkban (a vastaggal jelölt altémák átlag feletti gyakoriságot jelentenek) 
2. táblázat. Az interjúkban megjelenô fô- és altémák előfordulásainak száma

\begin{tabular}{rc}
\hline Fó- és altémák & $\begin{array}{c}\text { Elófordulások száma } \\
\text { az interjúkban }\end{array}$ \\
\hline Egészségmagatartás-változás & 63 \\
alvási szokások változása & 51 \\
egészségtelen táplálkozás & 12 \\
Egészségromlás $\quad 188$ \\
általános egészségromlás & 42 \\
alvászavar & 51 \\
kardiovégés & 22 \\
geszkuláris betegség, magas vérnyomás & 19 \\
beszédes tünetek & 15 \\
inzulinrezisztencia, diabétesz & 13 \\
túlsúly & 9 \\
mozgásszervi megbetegedés & 9 \\
\hline
\end{tabular}

bemutatás eszközével, idézetek segítségével mutatjuk be, illetve tématérkép (1. ábra) segítségével illusztráljuk a foobb témákat és altémákat. A 2. táblázatban pedig összefoglaljuk, hogy az egyes témákhoz és altémákhoz tartozó kódok hány alkalommal fordultak elố a 29 interjúban.

A továbbiakban részletesen bemutatjuk az interjúk elemzésének eredményeképpen meghatározott fơ témákat és altémákat. A témák rövid bemutatása mellett a résztvevôktôl vett idézetekkel illusztráljuk az eredményeket, így hangot adva az élményeknek, amelyeket a résztvevôk az egészségmagatartás-változással, valamint az egészségromlással átélnek a beszámolóik szerint.

\section{Egészségmagatartás-változás}

Az interjúalanyok a túlzott munkavégzéssel összefüggô egészségmagatartás-változásról, azon belül pedig fôként a táplálkozás és az alvási szokások megváltozásáról számoltak be.

\section{Egészségtelen táplálkozás}

„Hát az, hogy mondjuk átlag havi 400 órákat dolgozik egy ember, ha nem többet. Nagyjából. És hát a kóla, energiaital, hamburger és egyéb más 'junk food'-ok az élelmezési forrás." „Mindig ott bent kellett lenni, de amúgy este 11 az halál. Ugye ott normális vacsorák is kimaradnak, meg hasonlók." 
Alvási szokások meguáltozása

Jelentôs témaként jelent meg az alvási szokások megváltozása, amire az érintettek számos indokot neveztek meg. Az interjúkból négy csoport mintázata rajzolódott ki. Az egyik csoport, akik szeretnének aludni, de nem tudnak, mert a munkahelyi dolgok mennek a fejükben, „folytatják álmunkban a munkát”, ,agyalnak tovább”, „stresszelnek a munkán”, ezért ók „rettenetes alvók”, és volt, aki rémálmokkal küzdött.

„Tehát én mindig híres voltam arról, hogy lefekszem, kikapcsolom az agyamat és úgy alszom, mint a bunda reggelig. Az elmúlt idóben, években nem nagyon, ahogy ugye erôsödik a versenyhelyzet satöbbi. Az elmúlt idóben ez nem nagyon megy, és ha nem elégedetten fekszem le, akkor nem tudok aludni."

„Ha udvariatlan vagyok a kollégákkal az is, napokig nem alszom utána.”

A második csoportba tartoztak azok, akik azért nem aludtak, mert éjszaka dolgoztak különféle okokból, különbözó intenzitással: például ilyen volt a munka jellege, vagy az, hogy éjszaka volt idejük elvégezni a napközben elmaradó feladatokat.

„Ahogy abbahagytam az éjszakázást, ez helyreállt [az egészségügyi problémája]. Én ezt az éjszakázásnak tulajdonítom be."

„Volt amikor tényleg... A rekordom az, hogy 4 napig nem aludtam. Nem volt jó. És ha egyszer nem alszom, akkor utána rosszabb, szóval kivagyok egy-két napig legalább, és az úgy rossz."

A harmadik csoportba tartoztak azok az interjúalanyok, akik nem a munka miatt nem tudtak aludni, hanem egyéb tevékenységek végzése állt a háttérben, felvetve más viselkedési addikciók jelenlétét:

„Volt egy idôszakom, hogy elég sokáig is dolgoztam, aztán hazamentem, és akkor éppen nem volt párom, és pókereztem. Beiratkoztam egy versenyre este 8-kor, és mondjuk nem estem ki, csak hajnal 3-kor. És másnap mentem reggel dolgozni, tehát az iszonyatosan fárasztó volt."

„Számítógéppel játszottam nagyon sokat, és akkor az elég erôteljes volt. Volt olyan, hogy leültem és akkor órákat. Volt olyan, hogy nem lehetett hozzám szólni, mert azt sem vettem észre. [...] Éjszaka, na meg napközben is."

A negyedik csoportba pedig azok kerültek, akik nem is szerettek volna aludni, mert haszontalan idốnek tartották, vagy úgy gondolták, a munka miatt muszáj ébren vagy félig ébren tölteniük az éjszakát, hogy azonnal tudjanak reagálni. Többen megvonták maguktól az alvást.

„Volt egy idô, amikor csökkenteni próbáltam az alvásomat, hogy hány óra az, amit bírok. És akkor kitaláltam, hogy nagyjából mennyi, de aztán az felborul és most már nem figyelek én igy erre enynyire tudatosan.” [Kérdezö: „Tehát azért jelölte ki, hogy minél kevesebbet aludjon?”] „Igen, hogy a többit azt aktívan tudjam tölteni. Igen."

„Azt kívánom, hogy legyen valami szer, ami segít, hogy ne kelljen aludni. Tehát, hogy így napokat ne kelljen aludni, és akkor igy utolérném magam. Szeretnék mondjuk egy 52 órás napot, amikor nem kell aludni, és akkor megcsinálok mindent. 


\section{Egészségromlás}

A túlzott munkavégzés és egészségromlás témaköre általánosan vagy specifikusan is megjelent a 29 résztvevô beszámolójában a végzett munka jellegétôl, nemtôl és életkortól függetlenül. A beszámolókban megjelentek specifikus betegségek: inzulinrezisztencia, cukorbetegség, alvászavar, kardiovaszkuláris és gyomorbetegségek, elhízás. Az egészségromlást már meglévô betegség súlyosabbá válásában vagy új betegségek kialakulásában észlelték magukon. Ha nem csak az önmaguknak szabott mérce, de külsố tényezôk, mint munkahelyi problémák, átszervezés vagy túlkontrolláló fơnök is szerepelt a történetben, akkor az egészségromlást a munkatársaikon is megfigyelték.

\section{Általános egészségromlás}

Az általános egészségromlást a már meglévô betegségek kiújulásában, intenzitásának növekedésében (szemek fáradása, migrén) vagy gyorsabb öregedésként élték meg. „Hát... átlagban úgy érzem magam, mint egy 200 éves ember. Tehát gyakorlatilag [nevet] mindig mindenem fáj.”

\section{Mozgásszervi betegségek}

A meglévő vagy kialakuló mozgásszervi betegségeket a túlzott stresszel és a nem megfelelố munkakörülményekkel hozták összefüggésbe.

„Így a gerincsérvemre is nagyon csúnyán ráment ez a sok stressz.”

„Mert nyilván a hátam az fáj, elôtte is volt már gerincferdülésem. El se merek menni röntgenre, hogy most hogy néz ki a gerincem, mert ugye nincs hely a lakásban. Tehát vagy ágyon ülve dolgozom, vagy egy nagyon kényelmetlen étkezöasztalnál. Tehát az nagyon fáj, tehát azzal biztosan kellene foglalkoznom."

\section{Inzulinrezisztencia és diabétesz}

Az inzulinrezisztencia jeleinek megtapasztalása, valamint a diagnózis a túl sok munka vagy a túl sok stressz okozta egészségromlás élményével társult. A betegség következményeit fizikai tünetekben és a viselkedésváltozásban (pl. türelmetlenség) is megfigyelték önmagukon, amelyet a munkahely tényezóivel (pl. stresszes környezet, főnök) hoztak összefüggésbe.

„És hát az összes többi kollégánál inzulinrezisztencia, cukorbetegség, magas vérnyomás, tehát így kérdezte is az üzemorvos, hogy én a névsor végén, hogy «mit csinálnak itt magukkal»?”

Kardiovaszkuláris megbetegedések, magas vérnyomás

„Hát a vérnyomásom az elég magas. Most is küzdök amúgy vele. Egyrészt szerintem a munkából adódik a stressz, tehát az iszonyatosan nagy nyomás. A másik meg örökletes tényezó. Ez a kettô. És nekem ezért is muszáj, hogy sportoljak.” 
Alvászavar

„Most ez már jó pár hónapja tart, belecsúsztam egy [...], most már alvászavarnak hívnám [...], tehát nagyon nehezen alszom el. És hogy ez most már kezd ilyen extrém mértéket ölteni, hogy tényleg éjjel három, fél négy, hogy még látom az órát, megnézem az órát.”

\section{Gyomorbetegségek}

Az interjúalanyok közül sokan szenvedtek gyomorgyulladásban, gyomorfájdalomban vagy akár gyomorfekélyben is.

„Hát most nem tudom, hogy ettôl-e, de úgy tényleg gyomorfájdalmak, ami akkor múlt el, amikor vége lett a projektnek, akkor így szinte pillanatok alatt elmúlt. Tehát én is elmentem vele orvoshoz, meg gyomorfekély, már nyilván mindenre gondoltam, tehát az volt."

„Hát ez már így jelzés, hogy a gyomorgyulladás mitól alakulhat ki egy embernél, ha túltolja ezeket a dolgokat, meg ugye a stressz még rámegy.”

\section{Túlsúly}

Sokan szerettek volna megszabadulni túlsúlyuktól, terveznek fogyókúrába fogni, vagy azt sikernek megélni, ha vékonyabbak lehetnének. Volt, akinek a súlycsökkenés sokat segített az alvásminôségén vagy az egészségi állapotán.

„Hát a [cégnév]-nél volt ez a súlygyarapodásom, úgyhogy igen, az egyértelmú, hogy az egészség rovására ment."

\section{Fordulópont: az egészségromlás felismerése}

Az egészségromlás felfedezését mintegy fordulópontként írták le a személyek, amikortól elgondolkodtak a munkatempó csökkentésén, munkahelyváltáson, attitûdváltoztatáson. A fordulópontra úgy is utaltak az elbeszélésekben, hogy „elhasználódtak” a túlzott munkavégzésben. Ez némely esetekben elvezetett egyfajta önismereti felismeréshez, ami a saját munkához, eredményhez, teljesítményhez fúzôdô viszonyukat és a saját határaik, idejük, egészségük védelmét idézte elô. Ugyanakkor többen úgy számoltak be errôl a fordulatról, mint amely által jobban megismerték a saját magukat kizsákmányoló „személyiségüket”.

\section{Beszédes tünetek}

Olyan, számukra figyelemfelkeltô tüneteket meséltek el, amelyeket különösnek és „beszédesnek” értékeltek. Mintha a semmiból érkeztek volna, minden elôjel nélkül. Nem kapcsolták össze semmilyen egyéb betegséggel, ezeket pszichoszomatikus tüneteknek élték meg, ami késôbb arra ösztönözte ôket, hogy a túlzott munkavégzés és az egészségromlás között összefüggést keressenek. 
„Egyszer volt egy nagyon beszédes betegségem vagy nem is tudom, hogy mi. Hiszek benne, hogy minden ilyet magunknak generálunk. Semmi nem történt, nem voltam se megfázva, semmi, és elment a hangom. Nem tudtam beszélni, akármit tettem, nem tudtam és az egy nagyon tanulságos dolog volt, mert saját magamat próbáltam leállítani, hogy szünet legyen, mert munkaképtelenné tettem magamat azzal, hogy elment a hangom. Pedig nem volt semmi sem, se hangszálgyulladás, se megfázás, semmi, csak egyszerúen elment a hangom."

„Körülbelül 4 évvel ezelött volt egy rosszullétem, amikor úgy döntött a cégvezetés velem közösen, meg a nejemmel [nevet], hogy akkor változtatni kell az életmódon. Elájultam, feküdtem a földön, és úgy találtak meg. Senki nem tud róla semmit. Elvittek a kórházba. Elôször azt hitték, hogy stroke-ot kaptam, aztán elvittek az amerikai útra, ott vizsgálgattak két hétig, aztán megsimogatták a buksimat, és hazaküldtek, hogy akkor most én kipihentem magam."

Arról is beszámoltak az érintettek, hogy amiatt kezdték észrevenni, hogy valami gond van a munkavégzésükkel, mert romlott az egészségük.

„És volt egy pillanat, amikor olyan szinten romlott le az egészségügyi állapotom, hogy ez igy már nem ment tovább."

Kiégés mint az egészségromlás tünete

A kiégés gyakori téma az interjúkban, akár az „emberekkel való kommunikáció” miatt, akár mentális és fizikai fáradtság miatt. Többen utánaolvastak a témában, és így állapították meg, hogy vélhetốn ezen tünetek alapján ôk is kiégtek. Nem kevesen fiatalkorukban tapasztalták meg a kiégést.

„Észleltem magamon tüneteket, amik, miután elkezdtem erról olvasni, rájöttem, hogy a kiégéssel állok szemben."

\section{DISZKUSSZIÓ}

Jelen kutatás célja a munkafüggôség fizikai egészséggel, egészségromlással, stresszel és egészség-magatartással való kapcsolatának vizsgálata volt. Ehhez olyan személyeket kérdeztünk félig strukturált interjúk segítségével, akik egy előzetes felmérés alapján munkafüggôség szempontjából a kockázati csoportba kerültek. Kutatásunk egyik fő újdonsága és eredménye így abban mutatkozott meg, hogy a korábbi, elsôdlegesen kvantitatív kutatásokkal szemben lehetôségünk nyílt validált méróeszközök alapján toborozni a résztvevôket, akik a probléma szempontjából érintettek.

A korábbi - kvantitatív - kutatások ugyan megállapították, hogy a munkafüggóség számos kedvezôtlen testi és lelki egészségmutatóval jár együtt (Clark és mtsai, 2016), de nem derült ki belőlük, hogy a két tényezô között milyen irányú és mintázatú öszszefüggés mutatkozik. Jelen interjúk tematikus elemzése ugyanakkor egyértelmúen rámutatott, hogy az érintett személyek a fizikai egészségi állapotukban megjelenô panaszaikat a túlzott munkavégzés és munkafüggóség következményeként írták le. A testi tüneteknek és fizikai megbetegedéseknek széles palettája jelent meg a beszámolók során. Tartalomelemzéssel (kvalitatív témaelemzéssel) végzett elemzésünkben két fố témát azonosítottunk, majd azon belül tártuk fel az egyes, konkrétabb témákat 
az egészségre vonatkozóan. Már a témák elnevezése is utal az idôbeli tényezốre, a hosszmetszeti jellegre: arra, hogy a munkafüggóség miként hatott a személyek egészségi állapotára. A válaszok alapján ugyanis az derült ki, hogy a maladaptív munkavégzési mintázat negatív hatással volt a személyek egészségi állapotára, így az egyik fố témát egészségromlás kategóriaként azonosítottuk. Ennek keretében számos panasz és betegség fogalmazódott meg az interjúk során. Az érintettek azt élték meg, hogy általánosságban rosszabb fizikai állapotba kerültek a túlzott munkavégzés következtében, illetve magas vérnyomásról, szív- és érrendszeri tünetekrôl, gyomor- és emésztési problémákról, migrénes tünetekrôl, hátfájásról és gerincproblémákról, autoimmun betegségek (inzulinrezisztencia és diabétesz) kialakulásáról és igen gyakran alvással kapcsolatos problémákról számoltak be, és mindezt a munkával kapcsolatos túlzott elköteleződés eredményeként. Ezek az eredmények tehát egyrészt párhuzamba állíthatók más kutatások eredményeivel, hiszen különösen, ami a szív- és érrendszeri betegségeket (Salanova és mtsai, 2016), a hátfájást (Matsudaira és mtsai, 2013) és az alvászavarokat (Salanova és mtsai, 2016) illeti, más országokban és más módszertanú kutatásokban is feltárták az együtt járást a munkafüggóséggel kapcsolatosan. Eredményeink azonban felhívják a figyelmet arra, hogy a fizikai egészségi panaszok egy még szélesebb körét érintheti a maladaptív munkavégzés: mind emésztési és neurológiai panaszok, mind pedig autoimmun betegségek kockázatának fokozódásával is járhat a munkafüggôség. Mindezek mellett az érintettek olyan megmagyarázhatatlan, „beszédes” tüneteket is tapasztaltak, amelyeket egyértelmúen a túlzott munkavégzés számlájára írtak, és amelyek egy késôbbi kényszerpihenô hatására el is múltak. Ezen pszichoszomatikus tünetek a munkafüggóség szakirodalmában ez idáig nem kerültek a vizsgálatok fókuszába, ám a jövőbeli kutatásokban mindenképpen érdemes lenne alaposabban megvizsgálni ôket.

Az alvászavar és a munkafüggóség szoros együtt járását bár több kutatás is bizonyította (Salanova és mtsai, 2016; Kubota és mtsai, 2010, 2014), a mi eredményeink azzal árnyalják az eddigi tudásunkat, hogy jobban megérthetjük: milyen különbözô okai lehetnek annak, hogy a munkafüggố személyek alvási nehézségekkel küszködnek. Az egyik megfogalmazott oka az alvásproblémáknak, hogy az érintettek nehezen tudnak éjszaka kikapcsolni, és gondolatban félretenni a munkájukat. A teendôkön és munkahelyi gondokon való folyamatos „agyalás” megakadályozza óket abban, hogy kelló mennyiségben és minôségben aludjanak. Emellett a nagymértékú stressz és a túlhajszoltság rémálmokat is okoz számukra, ami szintén rontja az alvásminôséget. Egy másik gyakori jelenség, hogy az érintettek alvás helyett is dolgoznak. Ennek hátterében sokszor az áll, hogy a személyek addig nem képesek lazítani, amíg nyomasztja ôket a sok feladat. Ez a mintázat jól kapcsolódik ahhoz a kutatási eredményhez, miszerint a munkafüggô személyek magas perfekcionizmussal jellemezhetôk (Clark, Lelchook és Taylor, 2010; Girardi és mtsai, 2015). Ugyanakkor azt is megfogalmazták, hogy sokszor sajnálják is az idốt alvással tölteni, mivel a munkához viszonyítva haszontalan dolognak tartják. Végül az is visszatérô élmény volt, hogy az alvászavar és a munkafüggốség kapcsolatát valamilyen egyéb, harmadik tényezó is befolyásolta, pl. szerencsejáték vagy videójáték-használat: a túlzott munkavégzés és munkahelyi stressz levezetésére egyéb, akár viselkedési addikciókba is „belecsúszhat” a személy, és ez is akadályozza ôt abban, hogy éjszaka kellô mértékben kipihenhesse magát. A munkafüggôség egyéb 
viselkedési addikciókkal való kapcsolatát eddig még csupán néhány kutatás vizsgálta (Laconi, Trichard és Chabrol, 2015; Villella és mtsai, 2011), ám ezek szignifikáns pozitív kapcsolatokról számoltak be mind a problémás internethasználat, mind pedig a szerencsejáték-zavar vonatkozásában. Ezen a téren mindenképpen több kutatásra lenne szükség, hogy mélységében megismerhessük ezen viselkedési problémák összekapcsolódásának okait.

Az interjúkból arra is fény derült, hogy az egészségügyi panaszok és testi tünetek megjelenésének hátterében nem megfeleló egészség-magatartási szokások is fellelhetôk. Idetartozik a rendszertelen és egészségtelen táplálkozás, az ebbôl és az ülőmunkával töltött idố dominanciájából fakadó súlygyarapodás, illetve a megfelelô mennyiségú pihenés és alvás hiánya. A tartalomelemzésünk során azonosított másik fő téma szintén implikálja a munkafüggóség és az egészségi állapot közötti kapcsolat folyamat jellegét: az egészségmagatartás-változás mint kategória azt fejezi ki, hogy az érintettek egyrészt azt is megélték, hogy a túlzott munkavégzés miatt kedvezôtlen irányba változott az egészség-magatartásuk, másrészt, egy fordulópontot követôen arra jöttek rá, hogy saját érdekükben változtatniuk kell életmódjukon. Ezek az eredmények felhívják a figyelmet a más kémiai és viselkedési addikciókkal kapcsolatos hasonlóságokra: az adott tevékenység - jelen esetben a munka, míg más esetekben a drog, a játék vagy egyéb magatartásformák - annyira eluralkodnak a személy életén, hogy annak káros következményeit az élet különböző területein, így testi és lelki egészség állapotán is megtapasztalja. Másrészrôl az is igen gyakori más addikciós zavarokban is, hogy a személynek valamilyen krízishelyzetet kell megélnie ahhoz, hogy észlelje az adott magatartás maladaptív jellegét. Hasonló eredményeket talált Russell (2013) is amerikai munkafüggók körében: ôk akkor ismerték el a munkafüggôség jelenlétét, amikor valamilyen szembetûnố negatív változás történt az életükben, például tönkrement a párkapcsolatuk.

Kutatásunk újszerúsége, hogy a munkafüggôség szempontjából érintett személyeket a kvalitatív témaelemzés módszerével vizsgáltuk. Ezen módszertan hazánkban kevéssé használt eljárás, holott számos különbözô jelenség megismerésére alkalmazható, különbözó populációkban. A témaelemzés módszerével vizsgáltak már többek között szexuális erôszakot elszenvedô hetero- és biszexuális személyeket (Braun, Terry, Gavey és Fenaughty, 2009), policisztás ovarium szindrómában szenvedô nôket (Kitzinger és Willmott, 2002), illetve fiatal egyedülálló nôket a rájuk nehezedô, nemi szerepekkel kapcsolatos elvárásokról (Pickens és Braun, 2018). Olyan kutatás azonban ez idáig még nemzetközi szinten sem történt, amelyben munkafüggóség szempontjából érintett személyekkel készített interjúkat elemeztek a témaelemzés módszerével. Kutatásunk összességében rávilágított arra, hogy a munkafüggôség szempontjából érintett személyek számos fizikai problémáról, testi panaszról és betegségrôl számolnak be, melyet egyértelmúen a túlzott munkavégzésnek tulajdonítanak. Ez egyértelmú bizonyítéka annak, hogy a munkafüggóség nem egy „pozitív addikció”, ahogy ezt laikus körökben tévesen hiszik (Robinson, 1998; Kun, 2018), és ahogy erre egyes szakemberek utalnak (Buelens és Poelmans, 2004). Maga a „pozitív addikció” fogalma önmagában is egy téves megközelítés, hiszen az addiktív zavarok egyik kulcsjellemzője, hogy az adott tevékenység már káros hatással van a személyre és környezetére nézve. Ez a munkafüggôség esetében is igaz, így ezt a megközelítést mindenképpen szükséges 
elvetnünk. Eredményeink pedig aláhúzzák a munkafüggóség addiktológiai megközelítését, hiszen a túlzott munkavégzés ártalmas következményeit maguk az érintettek is érzik. Jelen kutatásban csupán a fizikai egészséggel kapcsolatos tényezókre fókuszáltunk, ám számos vizsgálat mutatja azt is, hogy a munkafüggóség párkapcsolati és családi konfliktusokkal (Flowers, Robinson és Carroll, 2000; Balducci, Avanzi, Consiglio, Fraccaroli és Schaufeli, 2017), illetve munkahelyi konfliktusokkal és kontraproduktív munkahelyi viselkedéssel jár együtt (Balducci, Cecchin, Fraccaroli és Schaufeli, 2012; Clark és mtsai, 2016). Eredményeink tehát további bizonyítékként szolgálnak azon mítosz ledöntésével kapcsolatosan, hogy a munkafüggôségnek nincsenek negatív következményei, és ha vannak, azok legfeljebb pszichoszociális természetúek (Griffiths és mtsai, 2018; Kun, 2018).

\section{A kutatás korlátai}

Jelen kutatás több limitációval is jellemezhetô. Egyrészt, az interjúk kb. 1,5 ével az azt megelôzô, kvantitatív kutatás után készültek, és ennyi idô alatt a résztvevook munkavégzésében történhettek változások. Ugyanakkor az interjúk általános retrospektív jellege miatt ez nem jelentett kiemelt problémát. Bizonyos esetekben ez még pozitív hozadékot is jelenthetett, mivel volt olyan interjúalany, aki idóközben már kilábalt munkafüggó idôszakából, így már a változás élményeirôl is be tudott számolni. Ezzel együtt természetesen az emlékezeti folyamatok mindenképp torzíthatták a válaszaikat. Másrészrôl a vizsgálat külsố validitása korlátozott az alacsony elemszám miatt. Harmadrészt a kutatásunkban olyan személyeket kérdeztünk, akik egy megbízható és valid szûrôteszten munkafüggóség szempontjából a veszélyeztetett csoportba kerültek - ugyanakkor a mérôeszköz elsôsorban csak a magas kockázatot jelöli, a tényleges addikciót diagnosztikus értékkel nem állapítja meg (amiatt sem teheti, mivel a munkafüggôségnek jelenleg nincsenek hivatalos diagnosztikus kritériumai). A magas kockázat/veszélyeztetettség pedig nem feltétlenül jelenti, hogy valaki ténylegesen munkafüggôségben szenved. Jövôbeli kutatásoknak érdemes volna olyan módszereket alkalmazniuk, amelyben még pontosabban megállapítható a zavar aktuális jelenléte. Az interjúink során ugyanakkor megerôsítést nyert, hogy minden résztvevônek vagy aktuálisan vagy a közelmúltban volt problémája ezzel a jelenséggel. Negyedrészt, az interjúkat több (összesen nyolc) személy vette fel, ez pedig torzításokat okozhatott a kérdezési technikában való homogenitásban. Azonban a kvalitatív módszertanú vizsgálatok esetén az érvényesség és megbízhatóság biztosításának más eszközei vannak, mint egy kvantitatív vizsgálatban (Franbach, Van der Vleuten és Durning, 2013). A külsô érvényességet a kvalitatív vizsgálatokban a hitelesség növelésével érjük el, amelynek eszközei lehetnek a különbözó triangulációk (adat-, módszertani, elméleti vagy kutatói triangulációk). A vizsgálatban a kutatói triangulációt alkalmaztuk, vagyis két kutató is elemezte az adatokat. A külsô validitás a kvantitatív és a kvalitatív vizsgálatokban a bizonyítékok alkalmazhatóságát jelenti, míg ez a kvantitatív vizsgálatokban az általánosíthatóságban és a reprezentativitásban jelenik meg, a kvalitatív vizsgálatokban a transzferábilis jellemzô az antropológiai sû́rú leírásokban vagy azzal érhetô el, ha az eredményeket az ismert szakirodalommal összevetve részletes diszkusszióban jelenít- 
jük meg. A vizsgálat az utóbbit választotta. A reliabilitás fogalma a kvalitatív vizsgálatokban a szaturáció, az iteratív adatgyújtés vagy -elemzés eszközével ragadható meg. A mi vizsgálatunk az ismételt adatelemzést választotta. A kvantitatív vizsgálatoktól elvárt objektivitás a kvalitatív módszertannal végzett vizsgálat jellegébôl adódóan nem elvárható, ezért a kvalitatív vizsgálatok bizonyíthatóságát a folyamatos reflexivitás jellemzi. Vizsgálatunkban a folyamatos elméleti és a módszertani reflexivitást a heterogén kutatócsoport munkája biztosította.

\section{KÖVETKEZTETÉSEK}

Kutatásunkban egy olyan területtel foglalkoztunk, amelyet számos tévhit, vita és fenntartás övez laikus és szakmai körökben egyaránt (Billieux, Schimmenti, Khazaal, Maurage és Heeren, 2015; Kardefelt-Winther és mtsai, 2017). Azonban magukkal az érintettekkel, azaz a munkafüggóség szempontjából kockázati csoportba tartozó személyekkel készített interjúk azt mutatták, hogy a probléma nemcsak hogy létezik, hanem a túlzott munkavégzés számos kedvezôtlen tényezôvel, köztük egészségromlással, fizikai panaszokkal és betegségekkel jár együtt. Eredményeink felhívják a figyelmet arra, hogy a munkafüggóség egy olyan probléma, amely sokkal több figyelmet érdemelne - mind a felismerés és szürés, mind az intervenciók és a prevenció területén. Mindehhez azonban még több kutatásra lenne szükség, hiszen az okokat és a kezelési lehetôségeket illetôen rendkívül keveset tudunk a zavarról. A jövôben érdemes volna még több olyan - kvalitatív és kvantitatív - kutatást megvalósítani, amelyben munkafüggô személyek vesznek részt, hogy még mélyebben feltárjuk a jelenség mögöttes mozgatórugóit is.

\section{KÖSZÖNETNYILVÁNÍTÁS}

Kun Bernadette a Magyar Tudományos Akadémia Bolyai János Kutatási Ösztöndíjában és az Innovációs és Technológiai Minisztérium ÚNKP-19-4 kódszámú Új Nemzeti Kiválóság Programjának szakmai támogatásában részesült. A tanulmány elkészítését a Nemzeti Kutatási, Fejlesztési és Innovációs Hivatal támogatta (FK134807, KKP126835, Tématerületi Kiválósági Program 2020 - Intézményi Kiválósági Alprogram: TKP2020-IKA-05 )

\section{IRODALOM}

American Psychiatric Association (2013). Diagnostic and statistical manual of mental disorders. 5th ed. Washington, DC: American Psychological Association.

Andreassen, C. S., Griffiths, M. D., Hetland, J., Kravina, L., Jensen, F., \& Pallesen, S. (2014). The prevalence of workaholism: a survey study in a nationally representative sample of Norwegian employees. PLoS One, 9(8), e102446. https://doi.org/10.1371/journal.pone.0102446

Atlas.ti. (2018). ATLAS.ti Scientific Software Development GmbH. Qualitative Data Analysis. Version 8.0. Berlin. 
Atroszko, P. A., Demetrovics, Z., \& Griffiths, M. D. (2019). Beyond the myths about work addiction: Toward a consensus on definition and trajectories for future studies on problematic overworking. Journal of Behavioral Addictions, 8(1), 7-15. https://doi.org/10.1556/2006.8.2019.11

Atroszko, P. A., Demetrovics, Z., \& Griffiths, M. D. (2020). Work addiction, obsessive-compulsive personality disorder, burn-out, and global burden of disease: Implications from the ICD11. International Journal of Environmental Research and Public Health, 17(2), 660. https://doi. org/10.3390/ijerph17020660

Avanzi, L., Van Dick, R., Fraccaroli, F., \& Sarchielli, G. (2012). The downside of organizational identification: Relations between identification, workaholism and well-being. Work \& Stress, 26(3), 289-307. https://doi.org/10.1080/02678373.2012.712291

Balducci, C., Avanzi, L., Consiglio, C., Fraccaroli, F., \& Schaufeli, W. B. (2017). A cross-national study on the psychometric quality of the Italian version of the Dutch Work Addiction Scale (DUWAS). European Journal of Psychological Assessment, 33, 422-428. https://doi. org/10.1027/1015-5759/a000300

Balducci, C., Cecchin, M., Fraccaroli, F., \& Schaufeli, W. B. (2012). Exploring the relationship between workaholism and workplace aggressive behaviour: The role of job-related emotion. Personality and Individual Differences, 53, 629-634. https://doi.org/10.1016/j. paid.2012.05.004

Belkic, K. L., Landsbergis, P. A., Schnall, P. L., \& Baker, D. (2004). Is job strain a major source of cardiovascular disease risk? Scandinavian Journal of Work, Environment and Health, 30(2), 85-128. https://doi.org/10.5271/sjweh.769

Billieux, J., Schimmenti, A., Khazaal, Y., Maurage, P., \& Heeren, A. (2015). Are we overpathologizing everyday life? A tenable blueprint for behavioral addiction research. Journal of Behavioral Addictions, 4(3), 119-123. https://doi.org/10.1556/2006.4.2015.009

Booth-Kewley, S., \& Friedman, H. S. (1987). Psychological predictors of heart disease: a quantitative review. Psychological Bulletin, 101, 343-362.

Borbély, T. Ö., \& Pecze, M. (2006). A munkafüggôség (workaholism) szakirodalmának áttekintése. Addiktológia, 5(4), 359-381.

Bôthe, B., Potenza, M. N., Griffiths, M. D., Kraus, S. W., Klein, V., Fuss, J., \& Demetrovics, Z. (2020). The Development of the Compulsive Sexual Behavior Disorder Scale (CSBD-19): An ICD-11 Based Screening Measure Across Three Languages. Journal of Behavioral Addictions, 9(2), 247-258. https:/ / doi.org/10.1556/2006.2020.00034

Brand, M., Rumpf, H.-J., Demetrovics, Z., Müller, A., Stark, R., King, D. L., et al. (2020). Which conditions should be considered as disorders in the International Classification of Diseases (ICD-11) designation of "other specified disorders due to addictive behaviors"? Journal of Behavioral Addictions [Epub ahead of print]. https://doi.org/10.1556/2006.2020.00035

Braun, V., \& Clarke, V. (2006). Using thematic analysis in psychology. Qualitative Research in Psychology, 3(2), 77-101. https://doi.org/10.1191/1478088706qp063oa

Braun, V., Terry, G., Gavey, N., \& Fenaughty, J. (2009). 'Risk' and sexual coercion among gay and bisexual men in Aotearoa/New Zealand-key informant accounts. Culture, Health \& Sexuality, 11(2), 111-124. https://doi.org/10.1080/13691050802398208

Buelens, M., \& Poelmans, S. A. (2004). Enriching the Spence and Robbins' typology of workaholism: Demographic, motivational and organizational correlates. Journal of Organizational Change Management, 17(5), 440-458. https://doi.org/10.1108/09534810410554470

Clark, M. A., Lelchook, A. M., \& Taylor, M. L. (2010). Beyond the Big Five: How narcissism, perfectionism, and dispositional affect relate to workaholism. Personality and Individual Differences, 48, 786-791. https://doi.org/10.1016/j.paid.2010.01.013 
Clark, M. S., Michel, J. S., Zhdanova, L., Pui, S. Y., \& Baltes, B. (2016). All work and no play? A meta-analytic examination of the correlates and outcomes of workaholism. Journal of Management, 42, 1836-1873. https://doi.org/10.1177/0149206314522301

Clark, M. A., Smith, R. W., \& Haynes, N. J. (2020). The Multidimensional Workaholism Scale: Linking the conceptualization and measurement of workaholism. Journal of Applied Psychology, 105(11), 1281-1307. https://doi.org/10.1037/apl0000484

Cooper, C. L., \& Davidson, M. (1987). Sources of stress at work and their relation to stressors in non-working environments. In: Kalimo, R., ElBatawi, M. A. E., \& Cooper, C. L. (Eds), Psychological factors at work and their relation to health (pp. 99-123). Geneva: World Health Organization.

Demetrovics, Z., \& Griffiths, M. D. (2012). Behavioral addictions: past, present and future. Journal of Behavioral Addictions, 1(1), 1-2. https://doi.org/10.1556/JBA.1.2012.1.0

Demetrovics, Zs., \& Kun, B. (2007). Viselkedési addikciók. In: Demetrovics, Zs (szerk.), Az addiktológia alapjai I. (pp. 133-225). Budapest: ELTE Eötvös Kiadó.

Demetrovics, Zs., \& Kun, B. (2010a). Az Addiktológia alapjai IV. Viselkedési függóségek. Budapest: ELTE Eötvös Kiadó.

Demetrovics, Zs., \& Kun, B. (2010b). A viselkedési függóségek és az impulzuskontroll egyéb zavarainak helye az addikciók spektrumán. In: Demetrovics, Zs., \& Kun, B. (szerk.), $A z A d-$ diktológia alapjai IV. Viselkedési függốségek (pp. 29-40). Budapest: ELTE Eötvös Kiadó.

Fassel, D. (1992). Working ourselves to death. London: HarperCollins.

Flowers, C., Robinson, B. E., \& Carroll, J. J. (2000). Criterion-related validity of the Marital Disaffection Scale as a measure of marital estrangement. Psychological Reports, 86(3), 1101-1103. https://doi.org/10.2466/pr0.2000.86.3c.1101

Frambach, J. M., Van der Vleuten, C. P. M., \& Durning, S. J. (2013). AM Last Page: Quality Criteria in Qualitative and Quantitative Research. Academic Medicine, 88(4), 552. doi: 10.1097/ ACM.0b013e31828abf7f

Frone, M. R. (1999). Work stress and alcohol use. Alcohol Research \& Health: the Journal of the National Institute on Alcohol Abuse and Alcoholism, 23(4), 284-291.

Ganster, D. C., \& Perrewé, P. L. (2011). Theories of occupational stress. In: Quick, J. C., \& Tetrick, L. E. (Eds), Handbook of Occupational Health Psychology (pp. 37-53). 2nd ed. Washington, DC: American Psychological Association.

Ganster, D. C., \& Rosen, C. C. (2013). Work stress and employee health: A multidisciplinary review. Journal of Management, 39(5), 1085-1122. https://doi.org/10.1177/0149206313475815

Girardi, D., Falco, A., Piccirell, A., Dal Corso, L., Bortolato, S., \& De Carlo, A. (2015). Perfectionism and presenteeism among managers of a service organization: The mediating role of workaholism. TPM-Testing, Psychometrics, Methodology in Applied Psychology, 22(4), 507-521. https://doi.org/10.4473/TPM22.4.5

Griffiths, M. D. (2005). A 'components' model of addiction within a biopsychosocial framework. Journal of Substance Use, 10, 191-197. https://doi.org/10.1080/14659890500114359

Griffiths, M. D. (2011). Workaholism: A 21st century addiction. The Psychologist: Bulletin of the British Psychological Society, 24, 740-744.

Griffiths, M. D., Demetrovics, Z., \& Atroszko, P. A. (2018). Ten myths about work addiction. Journal of Behavioral Addictions, 7, 845-857. https://doi.org/10.1556/2006.7.2018.05

Griffiths, M. D., \& Karanika-Murray, M. (2012). Contextualising over-engagement in work: Towards a more global understanding of workaholism as an addiction. Journal of Behavioral Addictions, 1, 87-95. https://doi.org/10.1556/JBA.1.2012.002

Kanai, A., Wakabayashi, M., \& Fling, S. (1996). Workaholism among employees in Japanese corporations: An examination based on the Japanese version of the Workaholism Scales. 
Japanese Psychological Research, 38, 192-203. https://doi.org/10.1111/j.1468-5884.1996. tb00024.x

Karasek, R. (1979). Job demands, job decision latitude, and mental strain: Implications for job redesign. Administrative Science Quarterly, 24, 285-306. https://doi.org/10.2307/2392498

Karasek, R., \& Theorell, T. (1990). Healthy work: stress, productivity, and the reconstruction of working life. New York: Basic Books, Harper Collins Publishers.

Kardefelt-Winther, D., Heeren, A., Schimmenti, A., Rooij, A., Maurage, P., Carras, M., \& Billieux, J. (2017). How can we conceptualize behavioural addiction without pathologizing common behaviours? Addiction, 112(10), 1709-1715. https://doi.org/10. 1111/add.13763

Kecklund, G., \& Akerstedt, T. (2004). Apprehension of the subsequent working day is associated with a low amount of slow wave sleep. Biological Psychiatry, 66, 169-176. https://doi. org/10.1016/j.biopsycho.2003.10.004

Kirrane, M., Breen, M., \& O'Connor, C. (2017). A qualitative study on the consequences of intensive working. Human Resource Development Quarterly, 28(2), 227-268. https://doi. org/10.1002/hrdq.21284

Kitzinger, C., \& Willmott, J. (2002). 'The thief of womanhood': Women's experience of polycystic ovarian syndrome. Social Science \& Medicine, 54(3), 349-361. https://doi.org/10.1016/ S0277-9536(01)00034-X

Kivimaki, M., Head, J., Ferrie, J. E., Shipley, M. J., Brunner, E., Vahtera, J., \& Marmot, M. G. (2006). Work stress, weight gain and weight loss: evidence for bidirectional effects of job strain on body mass index in the Whitehall II study. International Journal of Obesity, 30(6), 982-987. https://doi.org/10.1038/sj.ijo.0803229

Kristensen, T. S. (1996). Job stress and cardiovascular disease: A theoretic critical review. Journal of Occupational Health Psychology, 1(3), 246-260. https://doi.org/10.1037//1076-8998 .1.3.246

Kubota, K., Shimazu, A., Kawakami, N., Takahashi, M., Nakata, A., \& Schaufeli, W. B. (2010). Association between workaholism and sleep problems among hospital nurses. Industrial Health, 48(6), 864-871. https://doi.org/10.2486/indhealth.ms1139

Kubota, K., Shimazu, A., Kawamaki, N., \& Takahashi, M. (2014). Workaholism and sleep quality among Japanese employees: a prospective cohort study. International Journal of Behavioral Medicine, 48(6), 864-871. https://doi.org/10.1007/s12529-012-9286-6

Kuiper, N. A., \& Martin, R. A. (1989). Type A behavior: A social cognition motivational perspective. In: Bower, G. H. (Ed.), The psychology of learning and motivation: Advances in research and theory, Vol. 24. (pp. 311-341). New York: Academic Press.

Kun, B. (2018). Ten myths and twenty years: What we know and what we still do not know about work addiction. Journal of Behavioral Addictions, 7(4), 863-866. https://doi. org/10.1556/2006.7.2018.125

Kun, B., \& Demetrovics, Zs. (2010). Munkafüggóség. In: Demetrovics, Zs., \& Kun, B. (szerk.), Az Addiktológia alapjai IV. Viselkedési függóségek (pp. 307-329). Budapest: ELTE Eötvös Kiadó.

Kun, B., Urbán, R., Bôthe, B., Griffiths, M. D., Demetrovics, Z., \& Kökönyei, G. (2020). Maladaptive rumination mediates the relationship between self-esteem, perfectionism, and work addiction: A largescale survey study. International Journal of Environmental Research and Public Health, 17(19), 7332.

Kun, B., Magi, A., Felvinczi, K., Demetrovics, Zs., \& Paksi, B. (2020). A munkafüggốség elterjedtsége, szocio-demográfiai és pszichés háttere a hazai felnôtt lakosság körében: egy országos reprezentatív felmérés eredményei. Psychiatria Hungarica, 35(3), 289-306.

Kun, B., Takács, Zs. K., Richman, M. J., Griffiths, M. D., \& Demetrovics, Z. (2020). Work addiction and personality: A meta-analyitic study. Journal of Behavioral Addictions, 2020 Dec 23. Online ahead of print. doi: 10.1556/2006.2020.00097. 
Kvale, S. (1996). Interview Views: An Introduction to Qualitative Research Interviewing. Thousand Oaks, CA: Sage Publications.

Laconi, S., Tricard, N., \& Chabrol, H. (2015). Differences between specific and generalized problematic internet uses according to gender, age, time spent online and psychopathological symptoms. Computers in Human Behavior, 48, 236-244. https://doi.org/10.1016/j. chb.2015.02.006

Machlowitz, M. (1980). Workaholics: Living with them, working with them. Reading, MA: AddisonWesley.

Matsudaira, K., Shimazu, A., Fujii, T. Kubota, K., Sawada, T., Kikuchi, N., \& Takahashi, M. (2013). Workaholism as a risk factor for depressive mood, disabling back pain, and sickness absence. PLoS One, 8(9), e75140. https://doi.org/10.1371/journal.pone.0075140

Mazzetti, G., Schaufeli, W. B., \& Guglielmi, D. (2014). Are workaholics born or made? Relations of workaholism with person characteristics and overwork climate. International Journal of Stress Management, 21(3), 227-254. https://doi.org/10.1037/a0035700

Mosier, S. K. (1982). Workaholics: An analysis of their stress, success and priorities. Austin, USA: University of Texas at Austin.

Müller, A., Brand, M., Claes, L., Demetrovics, Z., De Zwaan, M., Fernández-Aranda, F., et al. (2019). Buying-shopping disorder - Is there enough evidence to support its inclusion in ICD-11? CNS Spectrums, 24(4), 374-379. https://doi.org/10.1017/S1092852918001323

Ng, T. W. H., Sorensen, K. L., \& Feldman, D. C. (2007). Dimensions, antecedents, and consequences of workaholism: A conceptual integration and extension. Journal of Organizational Behavior, 28, 111-136. https://doi.org/10.1002/job.424

Nishiyama, K., \& Johnson, J. V. (1997). Karoshi - death from overwork: occupational health consequences of Japanese production management. International Journal of Health Services, 27(4), 625-641. https://doi.org/10.2190/1JPC-679V-DYNT-HJ6G

Oates, W. E. (1971). Confessions of a workaholic: The facts about work addiction. New York: World Publishing.

Orosz, G., Dombi, E., Andreassen, C. S., Griffiths, M. D., \& Demetrovics, Z. (2016). Analyzing models of work addiction: Single factor and bi-factor models of the Bergen Work Addiction Scale. International Journal of Mental Health and Addiction, 14(5), 662-671. https://doi. org/10.1007/s11469-015-9613-7

Peter, R., Alfredsson, L., Hammar, N., Siegrist, J., Theorell, T., \& Westerholm, P. (1998). High effort, low reward, and cardiovascular risk factors in employed Swedish men and women: baseline results from the WOLF Study. Journal of Epidemiology \& Community Health, 52(9), 540-547. https://doi.org/10.1136/jech.52.9.540

Pickens, C., \& Braun, V. (2018). "Stroppy Bitches Who Just Need to Learn How to Settle"? Young Single Women and Norms of Femininity and Heterosexuality. Sex Roles, 79(7-8), 431448. https://doi.org/10.1007/s11199-017-0881-5

Porter, G. (1996). Organizational impact of workaholism: Suggestions for researching the negative outcomes of excessive work. Journal of Occupational Health Psychology, 1, 70-84. https:// doi.org/10.1037/1076-8998.1.1.70

Porter, G., \& Kakabadse, N. K. (2006). HRM perspectives on addiction to technology and work. Journal of Management Development, 25(6), 535-560. https://doi.org/10.1108/ 02621710610670119

Robinson, B. E., Post, P., \& Khakee, J. F. (1992). Test-retest reliability of the Work Addiction Risk Test. Perceptual and Motor Skills, 74(3), 926. https://doi.org/10.2466/pms.1992.74.3.926

Robinson, B. E. (1998). Chained to the desk: A guidebook for workaholics, their partners and children and the clinicians who treat them. New York: New York University Press. 
Rumpf, H. J., Achab, S., Billieux, J., Bowden-Jones, H., Carragher, N., Demetrovics, Z., et al. (2018). Including gaming disorder in the ICD-11: The need to do so from a clinical and public health perspective. Journal of Behavioral Addictions, 7(3), 556-561. https://doi. org/10.1556/2006.7.2018.59

Russell, L. D. (2013). Reconstructing the "work ethic" through medicalized discourse on workaholism. Journal of Applied Communication Research, 41(3), 275-292.

Salanova, M., López-Gonzáles, A. A., Llorens, S., Del Líbano, M., Vicente-Herrero, M. T., \& Tomás-Salvá, M. (2016). Your work may be killing you! Workaholism, sleep problems and cardiovascular risk. Work \& Stress, 30(3), 228-242. https://doi.org/10.1080/02678373.201 6.1203373

Salavecz, Gy. (2008). Munkahelyi stressz és egészség. In: Kopp, M. (szerk.), Magyar Lelkiállapot 2008 (pp. 288-297). Budapest: Semmelweis Kiadó.

Salavecz, Gy. (2011). A munkahelyi stressz és az egészség összefüggései hazai és nemzetközi viszonylatban. Doktori értekezés. Budapest: Semmelweis Egyetem, Mentális Egészségtudományok Doktori Iskola.

Sántha, K. (2017). Számítógéppel támogatott kvalitatív adatelemzés a hazai neveléstudományi PhD-képzésben. Képzés és Gyakorlat, 15(1-2). 159-173.

Schaef, A. W., \& Fassel, D. (1988). The addictive organization. San Fransisco, USA: Harper \& Row Publishers.

Scott, K. S., Moore, K. S., \& Miceli, M. P. (1997). An exploration of the meaning and consequences of workaholism. Human Relations, 50, 287-314. https://doi.org/10.1177/ 001872679705000304

Siegrist, J., \& Rödel, A. (2006). Work stress and health risk behavior. Scandinavian Journal Work Environmental Health, 32(6), 473-481. https://doi.org/10.5271/sjweh.1052

Spence, J. T., \& Robbins, A. S. (1992). Workaholics: Definition, measurement, and preliminary results. Journal of Personality Assessment, 58, 160-178. https://doi.org/10.1207/ s15327752jpa5801_15

Sussman, S. (2012). Workaholism: A review. Journal of Addiction Research \& Therapy, 10(Suppl 6), 4120. https://doi.org/10.4172/2155-6105.S6-001

Szokolszky Á. (2004): Kutatómunka a pszichológiában. Budapest: Osiris Kiadó.

Urbán, R., Kun, B., Mózes, T., Soltész, P., Paksi, B., Farkas, J., et al. (2019). A Four-Factor Model of Work Addiction: The Development of the Work Addiction Risk Test Revised (WART-R). European Addiction Research, 25(3), 145-160. https://doi.org/10.1159/000499672

Villella, C., Martinotti, G., Di Nicola, M., Cassano, M., La Torre, G., Gliubizzi M. D., et al. (2011). Behavioural addictions in adolescents and young adults: Results from a prevalence study. Journal of Gambling Studies, 27(2), 203-214. https://doi.org/10.1007/s10899-010-9206-0

World Health Organization (2018). International statistical classification of diseases and related health problems (11th Revision). https://icd.who.int/browse11/l-m/en.

Yang, X., Qiu, D., Lau, M., \& Lau, J. (2020). The mediation role of work-life balance stress and chronic fatigue in the relationship between workaholism and depression among Chinese male workers in Hong Kong. Journal of Behavioral Addictions, 9(2), 483-490. https://doi. org/10.1556/2006.2020.00026 


\title{
DETERIORATION OF HEALTH AND CHANGE IN HEALTH BEHAVIOR AMONG INDIVIDUALS AT RISK OF WORK ADDICTION: A QUALITATIVE STUDY
}

\author{
KUN, BERNADETTE - HAMRÁK, ANNA - KENYHERCZ, VIKTÓRIA - \\ DEMETROVICS, ZSOLT - KALÓ, ZSUZSA
}

Background and aims: An increasing amount of studies examine the risk factors and outcomes of work addiction. Several theories posited that work addiction associates not only to negative psychological and social consequences but work addiction leads to deterioration of health status. Most of the studies explore the relationship between work addiction and physical health by using cross-sectional quantitative methods and only a few amounts of qualitative studies analyzed the personal experiences of individuals with work addiction. The aim of the current study was to explore and analyze the associations between working habits, physical health status, and health behaviors among individuals at risk of work addiction.

Methods: In our previous study, applying a valid work addiction measure, we have identified a group of individuals who showed a high risk of work addiction and we asked them to participate in the current study. Finally, 29 individuals (15 males and 14 females) have been asked by a semi-structured interview. Topics of career orientation, working habits, work motivations, experiences of work addiction, and physical and mental health have been involved in the interviews. The texts of the interviews have been analyzed by qualitative content analysis, by using both deductive and inductive methods. We applied the six steps of thematic analysis by Braun and Clarke (2006).

Results: Individuals with a high risk of work addiction have reported several negative signs of deterioration of physical health as a consequence of excessive work, such as motoric diseases, autoimmune diseases, cardiovascular and gastrointestinal diseases, obesity, sleep disorders, and burnout. They have experienced negative changes in their health behavior too: unhealthy eating behaviors, lack of physical activity, and a lower need for sleep have been reported.

Conclusion: Our results have indicated that at-risk population considered physical health symptoms as consequences of excessive work and work addiction. Considering our results, work addiction is not a "positive addiction", moreover, the problem has to be conceptualized as a behavioral addiction because the negative consequences of overwork have been experienced by these individuals.

Keywords: work addiction, workaholism, physical health, qualitative, content analysis

A cikk a Creative Commons Attribution 4.0 International License https://creativecommons. org/licenses/by/4.0/) feltételei szerint publikált Open Access közlemény, melynek szellemében a cikk bármilyen médiumban szabadon felhasználható, megosztható és újraközölhetô, feltéve, hogy az eredeti szerzó és a közlés helye, illetve a CC License linkje és az esetlegesen végrehajtott módosítások feltüntetésre kerülnek. (SID_1) 